PART 3

CAREER GUIDANCE PRACTICE ACROSS THE LIFECOURSE 


\title{
16. CAREER GUIDANCE IN NORWEGIAN PRIMARY EDUCATION
}

\author{
Developing the Power of Dreams and the Power of Judgement
}

\begin{abstract}
This chapter presents the findings from an exploratory study of career guidance and career learning in primary schools in Norway. Most primary schools in Norway do not have strategies and policies for career guidance, and career learning is largely unknown as a concept. Nevertheless, they sometimes "unknowingly" engage in such activities. Many schools, in fact, implement several relevant initiatives to children's career exploration as part of, or outside of, formal curricula/subjects. The challenge is to develop such unintentional career learning into intentional career learning. This does not have to be a radical change in schools. Primarily, it is a question of awareness of career learning and recognition that the same activity or subject can have two effects.
\end{abstract}

\section{INTRODUCTION}

In the context of Norwegian schools, career guidance is situated within lower and upper secondary schools' activities (Mordal, Buland, \& Mathiesen, 2018; Buland et al., 2011). However, one can argue that this is too narrow an understanding, and that career guidance is relevant in different ways throughout the entire educational system. Section 22 of the Education Act (2014) states that pupils have the right to receive career guidance, and that the service should be available to pupils at their individual schools throughout primary and secondary education and training.

Career guidance in the educational system aims to raise awareness and support pupils in choosing an education and future vocation. In addition, career guidance contributes to the students' development of the career competences that they will utilise throughout life (Neary, Dodd, \& Hooley, 2015). Based on relevant public documents on schooling and education in Norway, this type of guidance does not seem to be a priority either for primary schools (levels $1-7$, with a span of 6-13 years of age) or for the policy makers and administrators (see, for example, Official Norwegian Report, 2003; "Kultur for læring", 2003-2004; Buland et al., 2011; Mordal et al., 2018). 
The statement in the Official Norwegian Report (NOU) (2003:16), called 'First and foremost. Higher quality in compulsory education for all', only refers to career guidance in lower and higher secondary schools. The Education Act (2014) states that guidance should take place as a continuous process starting in lower secondary school. Although this is the only place that the law mentions grade levels, it is not explicitly stated that this is not relevant for primary schools. In practice, career guidance in Norway starts in lower secondary school, in the 8th grade (Buland et al., 2011). For this reason, in the absence of specifications, and based on an understanding of career guidance as being concerned solely with the pupils' choice of upper secondary school and higher education, when asked about activities related to career guidance or career learning, primary schools tend to answer that no such activities are taking place (Mordal et al., 2018). We find that the Nordic countries have some similarities with regard to career guidance and primary school (Euroguidance Sweden, 2015; Euroguidance, 2011; Skovhus, 2018). The law does not specify that career guidance is reserved for secondary schools; however, in practice, this activity is reserved for lower and higher secondary school students, and is aimed, to a degree, at supporting the educational decisions that young people face at that time (Euroguidance Sweden, 2015; Euroguidance, 2011; Skovhus, 2018).

Over the years, relatively little research has focused on children (aged 0-12) and their career development. Only 3\% of all articles about career development over the past 20 years have focused on children's career development (Watson, Nota, \& McMahon, 2015). Hartung, Porfeli, and Vondracek (2005) concluded that the literature in the field was fragmented in terms of disciplines, age range, and context. They indicated that there was a need for a more holistic perspective on children's career development, and that a comprehensive and coherent perspective on children's career development is lacking. They also problematize the fact that most research on children and career development has focused on what children know about career and work, rather than how the children have acquired this knowledge (Watson \& McMahon, 2005; Watson et al., 2015). Watson, Nota, and McMahon (2015) described possible directions for future research on children and careers and pointed out both the need to focus on younger children and the need for more closely linked research and policy design and practice development, rather than the limited focus on socioeconomic inequalities and children with disabilities. Kashefpakdel, Rehill, and Hughes (2018) underscore that there is a need for more research on careerrelated learning activities and programmes that have an observable, consistent and replicable impact on children.

This chapter is based on a study of career guidance in primary schools conducted on behalf of the Norwegian Directorate of Education in 2017/2018 (Mordal et al., 2018). During the project, we conducted individual qualitative interviews with representatives of school owners in six municipalities. Based on these interviews, we selected four case schools for visits. During the visits, representatives of school leadership, teachers, and pupils in 4th and 7th grade participated in separate focus group interviews. In the interviews with teachers and leaders, we asked questions 
about their understanding of guidance and career guidance in primary school, how career guidance can be relevant for them, and if they had any routines or structures for career guidance or any special routines in accordance with the transition to secondary school. The students were asked what they wanted to be when they got older, if they were learning about different occupations, and if they wanted to learn more about working life. We also asked them if and with whom they talked about their future work life, if they had visited any workplaces nearby, and if they had been learning anything about life skills. We interviewed 68 people in total, 6 school owners, 11 school leaders, 14 teachers, 18 pupils in 7th grade, and 19 pupils in 4th grade.

This project has opened a window to a fairly unexplored area in Norway. Norwegian primary schools have had little awareness of the fact that career guidance is relevant for them, and the research field has largely shared this perception. We, therefore, know little about this important part of the career guidance field. We assume the reason schools did not think this was relevant to them is the common understanding of the law that career guidance is primarily oriented towards the choice of upper secondary school, and that primary school students are not yet capable of thinking about educational and career choices. Due to such beliefs, career guidance is primarily regarded as a secondary and upper secondary school matter. These facts can also explain why our recruiting process was so difficult. Many of the schools we contacted did not feel that the theme of the project pertained to them. We used the words 'counselling' and 'career counselling' instead of 'guidance' when contacting the schools, since the primary schools seemed to be even more unfamiliar with the term 'career guidance'.

\section{CONCEPTUALISATION OF CAREER AND CAREER LEARNING}

The concept of careers is often understood as a synonym for individuals climbing in a hierarchical system of occupation, thereby making a career. Both in the academic and practical fields of career guidance, traditional career theory has often emphasised the need to help pupils make the best choice amongst relatively stable and well-known alternatives (Skovhus, 2018; Haug, 2018; Mathiesen, Mordal, \& Buland, 2014). This has been the dominant understanding of career guidance, which is often tied to Parsons's (1909) theory of rational choices. The theory is based on a person's accurate understanding of his or her individual traits (aptitudes, interests and personal abilities), a knowledge of jobs and the labour market, and a rational and objective judgment about the relationship between his or her individual traits and the labour market itself (qtd in Andreassen, Hovednak, \& Swahn, 2008).

Today, a broader understanding of careers is slowly becoming more influential. Thomsen and Skovhus (2016) described careers, writing, 'These contexts [education, work, leisure and family] create a complexity that requires daily handling to become meaningful to the individual. This is called a career, and in this is the understanding that a career is something that all people have' (Thomsen \& Skovhus, 2016, 
pp. 38-39, our translation). Career competencies are also understood more broadly, as Thomsen (2014) stated: 'Career competences are skills needed to understand and develop yourself, explore life, learn and work as well as handle life, learn and work in change and transition. It is an awareness of what you do, but also what you can do. The individual is shaped by his way of life and actions whilst affecting his own future opportunities' (p. 4).

This new concept of career opens up a broader understanding of the aims and activities involved in career guidance. Decisions about education and occupation are only some of the many decisions that people must make to live their lives in the best possible way. This way of looking at careers is contributing to a gradual change in the school system, from the traditional understanding of career guidance to a greater emphasis on career learning. Career learning in Norwegian schools is slowly changing focus, and practitioners now see it more as a question of life-long learning, providing pupils with the necessary career competence to handle a series of career choices that will confront them during the rest of their lives (Mordal et al., 2018; Buland et al., 2011). The goal of career learning will, therefore, be to help the individual pupil to develop an adequate understanding of the world that can provide the base for the pupil's later transitions in life (see, for example, Law, 1996). This includes a number of different academic activities linked to providing extended knowledge of social and working life, as well as the pupil's own preferences and interests.

\section{THE IMPORTANCE OF TALKING ABOUT CAREERS IN PRIMARY EDUCATION}

Children's career ambitions are an important starting point on the road to working life. Flouri, Joshi, Sullivan, and Moulton (2017) discussed the individual, family and contextual antecedents of children's aspirations. Flouri et al. (2017) described ambitions as personal goals that reflect what one wants to achieve. Generally, high ambitions are associated with positive future outcomes. Ambitions develop over time, from the imaginative to the concrete. As children become youths, they revise their ambitions based on their own skills and interests as well as on the influence from society and their parents (Flouri et al., 2017; Gottfredson, 2002, 2005). Flouri et al. (2017) concluded the discussion by saying that it is unclear if aspirations predict one's trajectories or if they simply reflect historical and societal contexts. In any case, there are important stages in the development of career ambitions that take place during the years of primary education (Gottfredson, 2002, 2005).

The most important individual difference in the nature of ambition is gender. To put it simply, girls tend to emphasise values associated with helping others, whilst boys tend to emphasise power and money. Flouri et al. (2017) found that girls tend to have "higher" aspirations and a greater motivation for school, whilst boys are more adventurous, confident in their abilities, and likely to strive for rare jobs. Girls choose between fewer jobs and are less engaged in career exploration (Hartung et al., 2005). The gender dimension is at least one of the major influences on choice, 
and Mathiesen, Buland, and Bungum (2014) describe it as a democratic problem. Watts (1996) claimed that this gendering comes to full strength in puberty (p. 359). Therefore, career learning should start earlier to weaken the strong impact of gender stereotypes on young people's choices.

Parents also have a major impact on children's career ambitions. Children from homes with a low socioeconomic status often have lower ambitions in terms of education and tend to dream of less prestigious professions than those coming from families with a higher socioeconomic status (Flouri et al., 2017).

Children are in the process of orienting themselves to the world, thus they try to understand how everything works. Therefore, they will learn about career and working life regardless of what their schools and parents do. Crause, Watson, and McMahon (2017) pointed out that there are two distinct categories of career development in childhood: the conscious (formal career learning) and the unconscious (what children see and hear in their surroundings). One must see these two forms in conjunction with career theory, research, politics and practice to develop a comprehensive understanding of how career development takes place in childhood. Providing children with career learning activities can help them think about possible career preferences and how subjects are relevant for their future working lives. The advantage both for the children and for the community is a more efficient management of decisions about careers and transitions. Crause, Watson, and McMahon (2017) emphasised that if society fails to give children skills in career learning, they may not be prepared well enough to handle their future development into adolescence and adulthood. Both theory and research underline the need for conscious career exploration in childhood.

\section{THE UNDERSTANDING OF CAREER GUIDANCE IN PRIMARY EDUCATION}

At the outset, the schools we visited understood career guidance as something with relevance from the start of lower secondary school and upwards in the system. In fact, an effort was sometimes necessary to convince the school that there was any point in visiting and doing interviews on this topic. With a few exceptions, most of our sources spontaneously understood 'guidance' as career guidance and something that was, therefore, not relevant to the primary level. Nevertheless, many interviews ended with an uplifting comment, such as: 'But, we are still doing a lot, in any case'. This indicates that the schools do not necessarily define activities as "careerrelated", but after our discussion with them, they saw how the given activities could help the pupils gain knowledge about careers and education, as well.

All our case schools had implemented social educational guidance through social and emotional learning programs and/or through positions with social educational guidance as an area of responsibility. Roles and responsibilities in this area were relatively clear, and phenomena like bullying were obviously high on the agenda. Our sources were, as stated, more dismissive in terms of career guidance; they considered it to be of little relevance. One informant interpreted the law and regulations as 
saying that this matter was something primary schools should not address; others thought that it should wait for lower secondary school. A few exceptions stated that knowledge about jobs and education was relevant, because some pupils were concerned with such topics.

Our informants in the schools unanimously told us that they had no clear focus on activities related to career guidance and that this was not emphasised in the curriculum or in extracurricular activities. One informant told us, 'Sometimes the children talk about what they want to be when they grow up, but that is not something that is generally followed up and talked about'. Some informants also stated that it would be wrong to focus on career guidance at an early age. This opinion was justified by a fear of forcing pupils into the topic of educational choice at a time when it was not necessary, causing them unnecessary stress. The following statement expresses a common sentiment among teachers on this topic:

It is still several years before they have to make a choice of that kind. Young people must be allowed to develop this gradually and not be pressed to make a choice before they are ready.

Therefore, we needed to do some translating for the informants. During that process, many of them discovered that by teaching the pupils self-reliance, interpersonal skills, and creativity and as they used alternative learning arenas, the schools were involved in many relevant 'career guidance' activities. However, the activities were rarely seen through 'career glasses'. When we introduced a broader understanding of the concept of 'careers' together with the concept of career learning, instead of guidance focused on one singular choice of education, this opened up new understandings of their normal, ongoing activities.

Armed with this new understanding linked to the concept of 'life skills' (UNICEF, 2012), a majority of the informants emphasised the importance of teaching their pupils' skills and competences like critical and creative thinking, innovation, communication, endurance, self-esteem, participation, and cooperation. Therefore, their perspective on career learning changed from seeing it as irrelevant to seeing it as one of the most important activities in school. Many activities, both curricular and extra-curricular, thereby gained significant additional content. Many informants told stories of visiting a local bank or other businesses to gain a practical understanding of mathematics or other traditional subjects in school through the use of alternative learning arenas. During the interviews, the informants' consciousness expanded in the way that they gradually saw the same activity as an important way of giving the pupils insight into working life. They started to see the possibilities for their local environment to be used as learning arenas, not only for important curricular subjects but also for life skills and career competence. As one principal said:

When they start here in first grade, all the children, at least all the boys, are fascinated by the local construction firm, our closest neighbour. A lot of them want to be like the guys who work there when they grow up, driving the big 
machine and such. Still, in my time as principal here, we have not visited them once ... I've never seen the need or possibility of using them for an arena for learning about working life and local community.

This principal clearly observed parts of the children's natural, early curiosity and career exploration (Watson \& McMahon, 2017) but did not have a clear understanding of it as such. The same principal described how classes sometimes visited local shops and businesses to search for alternative learning arenas but with the sole aim of giving the pupils an understanding of the practical importance of mathematics or other school subjects. This informant clearly never understood it as career learning. Therefore, the school missed an opportunity to support the children's early career exploration (Lapan, Bobek, \& Kosciulek, 2017).

\section{HOW DO PRIMARY SCHOOLS IN NORWAY ORGANISE AND CONDUCT CAREER GUIDANCE?}

Primary schools in Norway do not normally appoint career counsellors, partly because it is only at the end of lower secondary school that pupils have to make a conscious choice about further education. However, this does not mean that career guidance cannot be of interest and relevance in primary school, even if it is not understood as such. In this section, we will describe some of the relevant activities we found in our study.

In several of the school subjects, especially in social science and history, our informants saw that working life and occupation were important themes, but no one expressed that this was a central part of the curriculum. Some also said that they sometimes talked about professions as motivation in different subjects, such as how mathematics can be used in engineering, or why it is important to be good at reading and writing to get a good job. The teachers talked about these things to show that the school provides knowledge that the pupils will benefit from, and to demonstrate that they try to make the teaching relevant for the pupils and their future.

An introduction to explorations of careers and education can consist of visiting the local community. What companies and resources exist? Where do the parents work? What professions exist? All the schools had a relatively wide range of activities that linked the school and the community together. Business visits were common, and the schools used parents and other external actors in teaching. A common aspect of such measures was that they were not primarily intended as career guidance/learning but rather as activities to 'get to know the local community' or 'do something other than ordinary school'. Largely, this was about learning through an expanded educational perspective, visiting companies and entering external arenas to reach learning objectives. At the same time, our informants often saw that these activities gave the pupils insights into professions and business sectors. Reflecting on such visits, they saw that working with different companies could have an indirect careerlearning effect, although the informants primarily thought of such activities as, for 
example, alternative learning arenas. The pupils talked about visits to places like museums, activity centres, farms, banks, local newspapers and local businesses, but it seems that they, to a small extent, linked these activities to career learning. In the words of a 4th grader:

We visited the junkyard not long ago. There we learned a bit about batteries and where things are to be disposed and such stuff. On Thursday, we will visit the museum, and in 7th grade, we'll visit the chocolate factory and eat lots of chocolate, as a celebration before we finish school.

In the comment above it is clear that the students primary focus is the competence objectives or the social element of the excursion, and not learning about the professions or the working life. At another school, a teacher told us:

We have visited the bank for several years, and then we get a tour of the bank and they tell about the work they are doing ... It's connected to the Young Enterprise Programme ... they learn about accounts and the economy and things like that, and the staff at the bank talks a bit about the various tasks of the bank, and that they are working on different things. I think it's very good that the pupils get to see inside a bank.

However, the annual visit to the bank was actually about personal finance and social studies, not about working at the bank. Thus, career learning is not the focus of such visits, but, as a side effect, the children do get to see inside a real firm, so career learning is taking place.

Some of the schools actively used parents in the learning process. For example, a parent who is an engineer or geologist could visit in classes and assist the teachers in the teaching of the subject. Some of the informants explained how career learning could be a side effect of this, in the way that some of the children would ask what it was like to work in such an occupation, what did engineers or geologists do, and so on. The schools invited representatives of local businesses and organisations as well as musicians and actors to attend classes but seldom with any focus on their occupation. Other activities that the informants saw as relevant were various activities and external programmes linked to learning life skills and attempts to prepare young people for handling difficulties in life. According to several informants, knowing oneself is a central skill that schools can help develop in children. In the words of one teacher: 'Awareness of what your strengths and challenges are, that's also a form of guidance'. Some of the informants, therefore, made the connection between career learning and work connected to the assessment of the pupils and especially self-assessment.

Several schools mentioned that they participated in various external programmes aimed at developing self-awareness and competence in making good choices. These were activities that the informants linked to career learning during the interviews. A common feature for many of these activities was that they neither had a fixed system for implementation and evaluation nor a way to systemise good practice 
and transfer knowledge to new teachers. To a certain extent, they were seen as a random occurrence, an event that depended on the individual teacher's initiative or an invitation from, for example, parents, businesses, or nearby farms.

\section{INTENDED OR UNINTENDED CAREER GUIDANCE}

The exploration and development of career competencies amongst children starts at an early age (Gottfredson, 2002). Young children are curious about different occupations; they play and form images of what they will be when they grow up based on the adults they observe. When they enter primary school, such career exploration has already gone on for several years (Watson \& McMahon, 2017) and will continue to do so into school, regardless of how schools and teachers address it.

As we have described, a majority of primary schools in Norway do not have intended strategies and policies in this field. Career learning is, to a large degree, still an unknown concept for the main actors in primary schools. Nevertheless, they still "unknowingly" engage in such activities. In fact, many schools implement a number of initiatives as part of or outside of formal curricula/subjects, which, in various ways, are relevant for children's career explorations. There is much emphasis in the schools on developing children's abilities to make good choices in life, in addition to developing imagination, creativity, stamina, resilience and the ability to deal with difficulties in life. These are linked to the broader concept of life skills that NOU (2015:8) defined as one of the multidisciplinary topics (p. 8) but they are not always connected to career learning as such. All the schools taught pupils that they can influence their own lives in one way or another. In addition, the schools described working with entrepreneurial skills as important for raising awareness amongst pupils, as well as creating and reinforcing curiosity for different professions and educations. However, there has been less focus on career learning than life skills as an overall theme.

At the same time, most schools have a number of activities that expose pupils to working life. The use of alternative learning arenas outside the classroom is common. These activities are, to a very small extent, understood as contributing to career learning. Nonetheless, many schools still operate with a narrow concept of 'careers', as was the case with the schools in our study, who understand career guidance and learning to be concerned with specific choices of education and/or occupation, pertaining to later ages. Furthermore, the focus of these activities is often restricted to the use of external learning arenas for the teaching of school subjects. The understanding of the career-learning dimension of such visits as a systematic way of teaching pupils about working life and familiarising them with the local community and businesses is limited.

Using a concept described by Watson and McMahon (2017), one can see the difference between unintentional and intentional career learning and career development in schools. In unintentional career learning, career learning is a slightly random side effect. It is rarely systematised and used as a tool for intentional career 
learning. Because of this, developing unintentional career learning activities into a more intentional process does not have to be a very big step in schools. Primarily, it is a question of consciousness, of understanding that the same activity or subject can have two effects. It is possible to teach, for example, mathematics or language, and, at the same time, contribute to the children's developing career competencies. This will give them a better base for the more goal-oriented career learning and career guidance they will encounter from the 8th grade. It is a question of developing a more systematic, methodical approach to children's natural curiosity and career exploration, as outlined by, for example, Barnes and McGowan (2017) and Lapan, Bobek, and Kosciulek (2017).

By changing the focus and wearing 'career glasses', the career part of activities can be easily enhanced, thus giving pupils in all grades a better insight into education and working life. A greater awareness of the variety that is available for them to select from, as well as a better understanding of themselves and their own preferences and choices, would be beneficial for the pupils' learning, well-being, coping, and future choices. The understanding of life skills as something that includes, in the words of Thomsen and Skovhus (2016), the fact that people live their lives across different contexts, such as education, work, leisure, and family, is highly relevant for primary school students.

One thing our informants thought was particularly relevant, and that they saw as an important part of counselling work in primary schools, was referred to as 'developing both the power of judgment and the power of dreaming'. Thus, career guidance was seen as an important task to contribute to the development of individual pupils' good judgment: thinking before acting, thinking critically to consider different alternatives and situations, and having enough faith in and knowledge of oneself and society to make the 'right' choices, both in professional and social settings.

However, it was also important to open the eyes of these pupils in primary school and show them that they can 'choose' traditional and untraditional professions, set high goals and become "whatever they want", but that this requires hard work and determination. The power of dreams does not consist solely in dreaming about the future but also in knowledge of how to get there, what it takes to realise a dream and the obstacles they will meet. Therefore, meeting good role models that can nourish more dreams is important (Mathiesen et al., 2014). The choices pupils make entering lower secondary school (about a choosing second languages and elective subjects) do not determine whether they reach their dreams. However, if they make the right choices, the path becomes a little easier. This corresponds to the message from the 7 th graders in our study: They wanted more knowledge about professions and education to be better equipped to make good choices and to come closer to finding out what their dreams are. They also ask for more information on what consequences the choices they make early in secondary school have for their future education. This need for more knowledge is highly recognisable from earlier projects as well (Buland, Mathiesen, \& Mordal, 2014). 


\section{GOING FORWARD}

As we see it, it is not appropriate for education authorities to impose more work on primary schools by requiring them to develop career-education-specific curricula. However, what seems appropriate is to raise awareness amongst school staff and school owners that the activities they already engage in, with small adjustments, can be made even more relevant and give pupils knowledge of education and professions. When visiting the bank or the store, teachers can, ask questions about what education one needs to acquire such a job. Occupations and education surround the pupils at all times, but to use the opportunity to talk about these matters, schools, teachers, parents, and pupils must put 'career glasses' on.

The message from our informants in the 7 th grade is that they need more knowledge about the decisions they need to make early in secondary school and the resulting consequences. Such information would include a basic knowledge about the education system, different professions and entering a career-learning process. With this information, they can start a reflection process about their own abilities and preferences regarding future participation and opportunities in working life. The pupils are very aware of the 'big and difficult' choice that is crucial for the rest of our lives. They often feel that they do not receive enough knowledge of the opportunities or enough time to reflect on what different options will entail. To counter this experience, starting the career-learning process earlier and making parents become allies and reflection partners for their children may be a possible solution.

Our study also shows that pupils in 7 th grade are motivated to learn about working life and education and that they want to start a career-learning process. It also shows that schools in our study unknowingly conduct career-learning activities. One way to support pupils career learning is to help the key actors in schools to consciously implement career-learning elements more explicitly in their activities and incorporate ways to talk about the topic, whether they are on a hike in the woods, visiting the local bank, or engaged in a maths lesson in the classroom.

\section{REFERENCES}

Andreassen, I., Hovednak, S. S., \& Swahn, E. (2008). Utdanningsvalg - identitet og karriereveiledning [Selection of education - Identity and career guidance]. Oslo, Norway: Fagbokforlaget.

Barnes, A., \& McGowan, B. (2017). Targeted career exploration and development programmes. In M. Watson \& M. McMahon (Eds.), Career exploration and development in childhood: Perspectives from theory, practice and research (pp. 172-185). New York, NY: Routledge.

Buland, T., Mathiesen, I. H., Aaslid, B. E., Haugsbakken, H., Bungum, B., \& Mordal, S. (2011). På vei mot framtida - men i ulik fart? Sluttrapport fra evalueringen av skolens rådgiving [On the road to the future - but at different speed? Final report from the evaluation of the schools counselling in Norway]. Retrieved from https://www.udir.no/globalassets/filer/tall-og-forskning/rapporter/2011/5/ sluttrapport_radgiving.pdf

Buland, T., Mathiesen, I. H., \& Mordal, S. (2014). “A skjønne itj, a våkne opp kvar dag å vil bli nå nytt a”. Skolens rådgivning i Møre og Romsdal, Sør-Trøndelag og Nord-Trøndelag ["I don't understand; I wake up every day and want to become something new”. School counselling in Møre og Romsdal, Sør-Trøndelag and Nord-Trøndelag]. Trondheim, Norway: NTNU Program for lærerutdanning. 


\section{S. MORDAL ET AL.}

Crause, E., Watson, M., \& McMahon, M. (2017). Career development learning in childhood. Theory, research, policy and practice. In M. Watson \& M. McMahon (Eds.), Career exploration and development in childhood: Perspectives from theory, practice and research (pp. 186-196). New York, NY: Routledge.

Euroguidance. (2011). Lifelong guidance in Finland. Helsinki: Ministry of Education and Culture.

Euroguidance Sweden. (2015). Career guidance in Sweden. Stockholm: Swedish Council for Higher Education.

Flouri, E., Joshi, H., Sullivan, A., \& Moulton, V. (2017). The antecedents of children's aspirations. In M. Watson \& M. McMahon (Eds.), Career exploration and development in childhood: Perspectives from theory, practice and research (pp. 89-99). New York, NY: Routledge.

Gottfredson, L. S. (2002). Gottfredson's theory of circumscription, compromise, and self-creation. In D. Brown (Ed.), Career choice and development (4th ed., pp. 85-148). San Francisco, CA: Jossey-Bass.

Gottfredson, L. S. (2005). Applying Gottfredson's theory of circumscription and compromise in career guidance and counselling. In S. D. Brown \& R. W. Lent (Eds.), Career development and counselling: Putting theory and research to work (pp. 71-100). Hoboken, NJ: John Wiley \& Sons.

Haug, E. H. (2018). Karrierekompetanser, karrierelcering og karriereundervisning. Hva, hvorfor, hvordan, for hvem og hvor? [Career competences, career learning and career education. What, why, how, for whom and where?]. Bergen, Norway: Fagbokforlaget.

Hartung, P. J., Porfeli, E. J., \& Vondracek, F. W. (2005). Career adaptability in childhood. Journal of Vocational Behaviour, 66, 385-419.

Kashefpakdel, E., Rehill, J., \& Hughes, D. (2018). What works? Career-related learning in primary schools. London: The Careers \& Enterprise Company.

Kultur for læring [A culture for learning] (2003-2004). White paper 30. Oslo: Kunnskapsdepartementet.

Lapan, R., Bobek, B., \& Kosciulek, J. (2017). School-based approaches promoting children's career exploration and development. In M. Watson \& M. McMahon (Eds.), Career exploration and development in childhood: Perspectives from theory, practice and research (pp.159-171). London: Routledge.

Law, B. (1996). A career-learning theory. In A. G. Watts, B. Law, J. Killeen, J. M. Kidd, \& R. Hawthorn (Eds.), Rethinking careers education and guidance - Theory, policy and practice (pp. 46-71). London: Routledge.

Mathiesen, I. H., Buland, T., \& Bungum, B. (2014). Frihet til å velge kjønnstradisjonelt? Skolens rådgiving mellom underbygging og utfordring av ungdoms valg av yrker og utdanning [Free to choose gender-traditionally? The school's counselling between supporting and challenging youth's choice of professions and education]. In A. T. Hestbek \& C. Haugen (Eds.), Pedagogikk, politikk og etikkDemokratiske utfordringer i norsk (pp. 290-308). Oslo, Norway: Universitetsforlaget.

Mathiesen, I. H., Mordal, S., \& Buland, T. (2014). En rådgiverrolle i krysspress? Lokal variasjon og konsekvenser for rådgivningen i skolen [The role of career counsellors under cross-pressure? Local variation and consequences for school counselling]. Sosiologi i dag, 4, 57-78.

Mordal, S., Buland, T., \& Mathiesen, I. H. (2018). Det er bare snakk om hvilke briller man har på ... En studie av rådgiving på barneskolen [It's just a matter of what glasses you are wearing ... A study of counselling in primary schools in Norway]. Retrieved from https://www.udir.no/tall-og-forskning/ finn-forskning/rapporter/radgivning-i-barneskolen/

Neary, S., Dodd, V., \& Hooley, T. (2015). Understanding career management skills: Findings from the first phase of the CMS leader project. Derby: International Centre for Guidance Studies, University of Derby.

Norges offentlige utredninger (NOU) 2003:16. (2003). I første rekke. Forsterket kvalitet $i$ en grunnopplaering for alle [First and foremost. Higher quality in compulsory education for all]. Oslo, Norway.

Norges offentlige utredninger (NOU) 2015:8. (2015). Fremtidens skole - Fornyelse av fag og kompetanser [The school of the future. Renewal of subjects and competences]. Oslo, Norway.

Skovhus R. B. (2018). Vejledning - råd og lcering [Guidance - Advice and learning]. Aarhus, Denmark: Trykværket. 
The Education Act. (2014). Act relating to primary and secondary education. With amendments as of 25 June 2010, 31 May 2011, 2012, 2013 and 2014 (in force as of 1 August 2014). Oslo, Norway: The Ministry of Education and Research.

Thomsen, R. (2014). A Nordic perspective on career competences and guidance-Career choices and career learning. A concept note on career competences prepared for NVL \& ELGPN. Oslo, Norway: NVL.

Thomsen, R., \& Skovhus, R. B. (2016). Karrierekompetence i skolen [Career competence in school]. In L. G. Lingås \& U. Høsøien (Eds.), Utdanningsvalg-Identitet og danning (pp. 37-56). Oslo, Norway: Gyldendal.

United Nations International Children's Emergency Fund (UNICEF). (2012). Global evaluation of life skills education programmes. New York, NY: United Nations Children's Fund.

Watson, M., \& McMahon, M. (2005). Children's career development: A research review from a learning perspective. Journal of Vocational Behavior, 67, 119-132. doi:10.1016/j.jvb.2004.08.011

Watson, M., \& McMahon, M. (Eds.). (2017). Career exploration and development in childhood: Perspectives from theory, practice and research. New York, NY: Routledge.

Watson, M., Nota, L., \& McMahon, M. (2015). Child career development: Present and future trends. International Journal for Educational and Vocational Guidance, 15, 95-97. doi:10.1007/s10775-0159308-4

Watts, A. G. (1996). Socio-political ideologies in guidance. In A. G. Watts, B. Law, J. Killeen, J. M. Kidd, \& R. Hawthorn (Eds.), Rethinking careers education and guidance - Theory, policy and practice (pp. 351-365). London: Routledge. 